\title{
Dose-Response Relationship between Dietary Polyphenols from Acorns and Parotid Gland Hypertrophy in Pigs
}

\author{
Maria Grazia Cappai ${ }^{1 *}$, Petra Wolf ${ }^{2}$, Walter Pinna ${ }^{1}$, Josef Kamphues ${ }^{2}$ \\ ${ }^{1}$ Research Unit of Animal Husbandry Sciences, Department of Agriculture, University of Sassari, Sassari, Italy; ${ }^{2}$ Institute of Animal \\ Nutrition, University of Veterinary Medicine, Hannover Foundation, Bischofsholer Dam, Hannover, Germany. \\ Email: ${ }^{*}$ mgcappai@uniss.it
}

Received July $11^{\text {th }}, 2012$; revised August $11^{\text {th }}, 2012$; accepted August $18^{\text {th }}, 2012$

\begin{abstract}
Proline contents of parotid glands (PG) in pigs constantly increase after the inclusion of different amounts of ripe hulled acorns in the diet providing high polyphenols levels. The dose-response relationship was estimated on natural hydrolizable tannins (expressed as tannic acid equivalent TAE) amounts of 25.8 to $36.1 \mathrm{~g} \mathrm{TAE} / \mathrm{kg}$ DM in experimental diets. Macroscopic and histological morphometry of parotid glands greatly varied according to feed intake and dosages of TAE ingested. The PG response (hypertrophy grade) on acorns' tannins content in the diet was positively correlated ( $\mathrm{R}^{2}$ $=0.748$ ): the response to the protein precipitating activity (PPA) of tannins consisted of a functional parotidomegaly (hypertrophy), 1.34 up to 3.55 folds than control PGs, following an oral dosage 0.596 up $1.72 \mathrm{TAE} \mathrm{g} \cdot \mathrm{kg}^{-1}$ body weight $\cdot \mathrm{d}^{-1}$ respectively, after one week exposure.
\end{abstract}

Keywords: Acorns; Parotid Gland; Polyphenols; Hypertrophy; Proline; Secretory Response

\section{Introduction}

\subsection{Salivary Glands and Physiology of Secretion}

Salivary glands cover several physiological functions. The usefulness of saliva can be underlined in a series of multiple biological activities, as it moistens food and dissolves some constituent of it to provide the stimulation for taste receptors; helps to form the food particles into a bolus in order to ease the swallowing and passage through cranial parts of the gastrointestinal tract; provides antibacterial enzymes (lysozime), but also a proper medium for microbes growth in ruminants by the neutralization of organic acids produced in the rumen during bacterial fermentation; plays a key-role in the urea cycle and is involved in the digestive role through salivary amylase, or ptyalin, which amylolytic property increases progressively from the cat, fox, dog, rabbit, guinea pig to the pig [1].

\subsection{Parotid Gland Secretory Activity as a First Line of Defense against Dietary Tannins}

Parotid glands and, to a minor extent, mandibular and submaxillary glands (depending on species and zoological order) are involved in the coping activity with tannins in food, by adapting their secretory function towards dietary biological active substances presence in the mouth. With

"Corresponding author. special regards to parotid gland, the response to those dietary active compounds modulate either quantitatively or qualitatively the salivation. Such strategy developed across animal species, throughout evolutionary adaptation to food seasonal availability and low to high amounts of tannins, can be reasonably considered as a flexible interaction between animals and environment

\subsection{Biological Role of Polyphenols}

As a matter of fact, polyphenolic compounds are plant secondary metabolites (PSM) which exert to some extent a protective measure for allowing the development of vegetal tissues and organs [2], conferring resistance against predators, above all birds $[3,4]$ and greenbugs [5] and microbial infection, like moulds [4,6] and bacteria [7-9], but also showing some ecological impact by a given control of vegetal sprouting: tannins bond to nitrogen in decaying vegetal tissue, contribute to the limitation of new organic matter building up in the soil [10]. From a nutritional point of view, high tannins diets consumption leads to different episodes in humans and animals. Scientific references report evident correlation between dietary polyphenols rich diets and health enhancing properties: antioxidant properties [11-13], antibacterial activity on different bacterial strains in vitro and in vivo [7,14-20], antiparasitic [21], antiulcerogenic [22-24] antidiarrhoic [25], 
antimutagenic [26-33], antitumor [34-38], and some neoplastic cell line apoptosis $[39,40]$. On the other hand, high tannins diets might also result in detrimental effects like hepatotoxicity $[41,42]$, toxic nephrosis [43], oesphageal cancer [44], depression of feed intake and growth rate in many animal species [45-51].

\subsection{Salivary Tannins Binding Proteins: The Role of Proline Rich Proteins (PRPs) across Animal Species}

The parotid gland hypertrophic response to counteract the protein precipitating activity exerted by acorns tannins from own previous trials (unpublished data) showed to be more intense in young pigs, rather than in elder pigs, but independent on time of exposure, when one week vs four 4 weeks of experimental feeding were compared: a very fast and constant reaction towards an inclusion of $50 \%$ of acorns in the diet (25.8 g TAE $/ \mathrm{kg} \mathrm{DM})$, started to be detected from $24 \mathrm{~h}$ on, after the first consumption of the acorns combined diet. As reported in literature, common characteristics of proteins and polypeptides with high affinity for tannins are their open loose structure, a high proline content and small size $[46,52,53]$. The capability of some animal species to counteract high dietary tannins was seen to be linked to salivary proline rich proteins (PRPs) ancestral function in the maintenance of oral health at a basal level of mucoproteins secretion, increased by high tannins presence in the diet [54], as observed in pigs [55], in which an increase up to a $16.8 \%$ of proline/crude protein ratio of parotid glands chemical composition was seen (Figure 1) after the inclusion of a $70 \%$ of acorns in the diet, providing high amounts of hydrolizable tannins (36.1 $\mathrm{g}$ TAE $\cdot \mathrm{kg}^{-1} \mathrm{DM}$, expressed as tannic acid equivalents). Clauss, et al. (2005) [56] refer that from carnivores through omnivores to exclusive plant-eaters, the dietary nitrogen level is progressively reduced while the presence of dietary tannins increases. Due to selective pressure, the evolutionary adaptation of animal species induced from a milder up to a stronger capability to cope with high tannins amounts in the diet, can explain why some species are able to counteract dietary tannins PPA while others do not $[56,57]$. Such evolutionary adaptation is more efficient in animals which might get advantage of a pulsed production of salivary tannins binding protein (TBP), increased from basal levels, depending on seasonal variation of tannins ingestion with food [56]. The hypothesis tested in the present study considered the correlation between different percentages of acorns inclusion in the diet (50\% and $70 \%$ of the diet, as fed) and the consequent parotid gland response in terms of hypertrophy grades and secretory activity at microscopic level of the gland to the different amounts of dietary tannins based on different dosages, in pigs used as an animal experimental model, capable to tolerate high amounts of tannins in the diet.

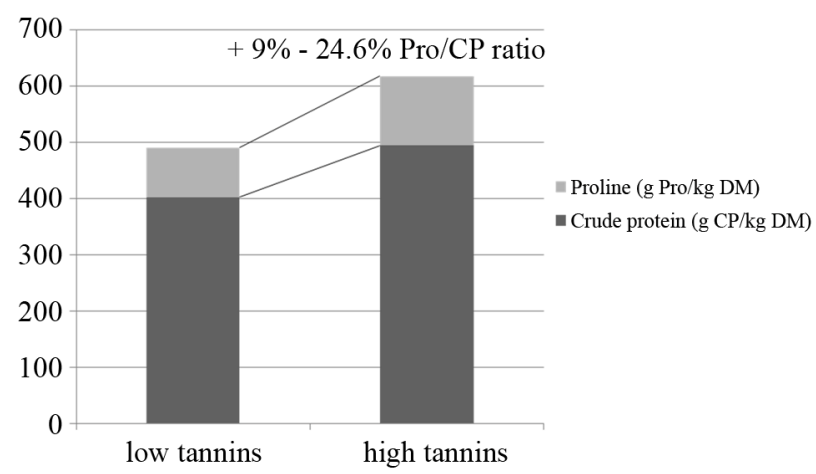

Figure 1. Analyzed chemical composition of parotid glands in pigs fed on control diet (left) vs acorns combined diet (right) for proline and crude protein contents. The proline/ crude protein ratio in pigs fed on acorns combined diets averagely increases of a $16.8 \% \pm 11 \%$ (Mean $\pm \mathrm{SD}$ ). In the graph, the range of values expressed as percentage is displayed on increased proline to total crude protein of parotid glands from pigs exposed to acorns tannins.

\section{Materials and Methods}

\subsection{Animals, Diets and Feeding Plan}

A total of 24 German Landrace cross-bred pigs without contact to acorns before, were fed three different experimental diets for 7 days. Different proportions of fresh acorns included in the diet were used: diet A, 70\% acorns, providing $36.1 \mathrm{~g} \mathrm{TAE} / \mathrm{kg} \mathrm{DM}$; diet $\mathrm{B}, 50 \%$ acorns, providing $25.8 \mathrm{~g}$ TAE $/ \mathrm{kg} \mathrm{DM}$; diet $\mathrm{C}, 0 \%$ acorns, providing undetectable TAE and representing the control, based totally on a pelleted complete diet. Chemical composition of the diets was determined by Weende analysis described by Naumann and Bassler (2004) [58] on replicates while the polyphenols contents were estimted by Folin-Ciocalteau (1927) method, modified by Waterman and Mole (1994) [59]. The chemical composition of the three experimental diets is reported in Table 1. Real intake of feed by each pig individually housed was reported daily and averaged to estimated DM intake/kg body weight and $\mathrm{g}$ TAE $\cdot \mathrm{kg}^{-1} \mathrm{BW} \cdot \mathrm{d}^{-1}$ ingested. All animals were sacrificed eight $\mathrm{h}$ after the last meal (on day 8).

\subsection{Parotid Glands Inspection and Microscopic Check}

Both PGs of each sacrificed pig were surgically removed from the carcass, taking care of the excision in toto. After removing the separable fat, lymphnodes and associated vessels, each PG was immediately weighed on a digital scale to report fresh weight (g). Morphometric characteristics and macroscopic evaluation at visual inspection followed specific standard criteria developed in own previous trials [55]. Relative fresh weight of each parotid gland was calculated according to the body weight (BW) of the respective animal and expressed as percentage. Left and 
Table 1. Analyzed chemical composition of the experimental diets.

\begin{tabular}{cccc}
\hline $\begin{array}{c}\text { The content of acorns (\%) in the diet } \\
\text { Chemical diet composition }\end{array}$ & 70 & 50 & 0 \\
\hline Dry matter (g/kg, as fed) & 695 & 751 & 890 \\
Crude protein (g/kg DM) & 113 & 116 & 175 \\
Crude Fibre (g/kg DM) & 112 & 95 & 45.0 \\
Crude Ash (g/kg DM) & 58.6 & 59.1 & 68.5 \\
Starch (g/kg DM) & 447 & 453 & 435 \\
Tannic Acid Equivalent $(\mathrm{g} / \mathrm{kg} \mathrm{DM})$ & 36.1 & 25.8 & $<1$ \\
\hline
\end{tabular}

right parotid glands were immediately fixed in formaldehyde $(10 \%)$ for histological analysis. After dehydration and waxy paraffin embedding, two $\mu \mathrm{m}$ thick tissues sections were stained using Haematoxylin-Eosin (HE) and Periodic Acid's Schiff stain (PAS). Slides were checked up by confocal microscope. Morphology and cytoplasm appearance of secretory cells followed criteria adopted in own previous trials [55]. Hyperplasia vs hypertrophy was evaluated. A statistic correlation and linear regression coefficients between tannins dosages and enlargement factors representing the parotidomegaly were calculated.

\section{Results}

\subsection{Daily Feed Intakes and Dietary Tannins Ingestion from Different Acorns Inclusion in the Experimental Diets}

The daily DM intake (in grams), expressed as percentage of body weight, did not differ statistically between pigs fed on diets including $50 \%$ either $70 \%$ of acorns. By contrast, daily DM intake in pigs fed on the control diet $(0 \%$ acorns), appeared lower. This was explained as a way to fulfill energy requirements of animals, since the dry matter contents of the diets differed according to the inclusion of fresh unprocessed acorns, responsible to reduce the energy density of the combined pelleted complete diet. In addition, acorns provide high amounts of crude fibres (including lignin, above all), resulting in reduced digestibility rate of organic matter and lower expected metabolizable energy of the diet. Feed intake depression from acorns tannins in the diet can be excluded and this finding is in contrast with references [45-51] on reduced feed intake in different animal species observed after high tannins (from different botanical origin or synthetic included in the formulation) inclusion in diets. Different dosages of ingested tannins $\left(\mathrm{g}\right.$ TAE $\left.\cdot \mathrm{kg}^{-1} \mathrm{BW} \cdot \mathrm{d}^{-1}\right)$ followed different DM intakes of combined diets, proportionally, up to a maximum of $1.71 \mathrm{~g} \mathrm{TAE} \cdot \mathrm{kg}^{-1} \mathrm{BW} \cdot \mathrm{d}^{-1}$.

\subsection{Parotidomegaly Occurrence and Macroscopic Score (Enlargement Factor, EF)}

Table 2 reports tannins intakes recorded throughout the experimental feeding (one week) for the three groups of animals according to acorns inclusion in the diet $(70 \%$ vs $50 \%$ vs $0 \%$ ) and entity of parotidomegaly, expressed as percentage of mass increase $(70 \%$ and $50 \%$ acorns combined diets groups) compared to the parotid gland from the control diet ( $0 \%$ acorns combined diets).

\subsection{Histological Evaluation of Parenchyma and Cells Activity}

The histological assessment confirms the hypertrophy of the parotid gland, according to the microscopic evaluation on cell activity and on the whole parenchyma: high cell turnover (mitosis), visible nucleoli (euchromatin, higher gene transcription, DNA encoding, etc.), higher cytoplasm/nucleus ratio (indicating secretory activity and salivary proteins release in the lumen of ducts). At light microscope as well as at confocal microsocope, the target cells under dietary tannins stimulation were identified in the secretory acinar cells of parenchyma, rather than ductal cells, represented as a cylindric monolayer epithelium, apparently not involved in the increased activity. As reported in references and in agreement with previous own trials, the increase of proline concentration in parotid glands of animals exposed to dietary acorns tannins shows the involvement of adenomeric cells to release high amounts of tannin binding proteins in the saliva (see Figure 1). No histopathological signs were detected in parotid glands examined, neither on acinar nor on ductal cells.

\subsection{Dose-Response Relationship between Dietary Tannins and Parotidomegaly}

A strong statistic correlation between parotodimegaly and dietary tannins ingestion per day according to $\mathrm{kg}$ of body weight was pointed out $(\mathrm{R}=0.864)$ and the linear regression coefficient $\left(\mathrm{R}^{2}\right)$ is also reported in Figure 2: the trend of parotid gland hypertrophy strongly depends on tannins dosages ingested per day, expressed according to $\mathrm{kg}$ of body weight. The analysis of the curve, shows a low difference of parotidomegaly ( 1.35 to 1.69 folds) in relation to tannins dosages between 0.60 and $1.35 \mathrm{~g}$ of TAE $\cdot \mathrm{kg}^{-1}$

Table 2. Daily acorns tannins intakes (g TAE $\cdot \mathrm{kg}^{-\mathbf{1}} \mathrm{BW} \cdot \mathrm{d}^{-\mathbf{1}}$ ) and parotidomegaly, expressed as enlargement factor. Data are reported as mean \pm SD.

\begin{tabular}{cccc}
\hline $\begin{array}{c}\text { The content of acorns } \\
(\%) \text { in the diet } \\
\text { Number of animals }\end{array}$ & 70 & 50 & 0 \\
\hline $\begin{array}{c}\text { Tannins intake on BW } \\
\left(\mathrm{g} \mathrm{TAE} \cdot \mathrm{kg}^{-1} \mathrm{BW} \cdot \mathrm{d}^{-1}\right)\end{array}$ & $1.43 \pm 0.01$ & $1.06 \pm 0.55$ & 0.001 \\
$\begin{array}{c}\text { Parotid gland relative weight } \\
\left(\mathrm{g} \cdot \mathrm{kg}^{-1} \mathrm{BW} \times 100\right)\end{array}$ & $0.425 \pm 0.0$ & $0.128 \pm 0.10$ & $0.088 \pm 0$ \\
Enlargement factor & $1.69 \pm 0.5$ & $1.45 \pm 1.18$ & - \\
\hline
\end{tabular}


$\mathrm{BW} \cdot \mathrm{d}^{-1}$. A more intense parotid gland response starts to be detected by increasing grades of hypertrophy (and secretory cellular activity) at tannins dosages higher than 1.34 $\mathrm{g}$ of TAE $\cdot \mathrm{kg}^{-1} \mathrm{BW} \cdot \mathrm{d}^{-1}$, up to a maximum of 3.55 folds of relative weight (corresponding to the dosage of $1.72 \mathrm{~g}$ of $\mathrm{TAE} \cdot \mathrm{kg}^{-1} \mathrm{BW} \cdot \mathrm{d}^{-1}$ ingested). From a mathematical point of view, the flex at $1.4 \mathrm{~g}$ of TAE $\cdot \mathrm{kg}^{-1} \mathrm{BW} \cdot \mathrm{d}^{-1}$ changes the direction of the curve and the trend of parotidomegaly is predicted to be of 2 folds of relative weight (treated vs untreated group). The response follows a sigmoid curve: at values on left side to the flex, small differences are seen up to $1.36 \mathrm{~g}$ of TAE $\cdot \mathrm{kg}^{-1} \mathrm{BW} \cdot \mathrm{d}^{-1}$ ingestion, but, from that dosage on, the parotidomegaly rapidly increases and the curve changes direction; the intense parotidomegaly continues to increase proportionally at dosages of 1.43 to $1.72 \mathrm{~g}$ of TAE $\cdot \mathrm{kg}^{-1} \mathrm{BW} \cdot \mathrm{d}^{-1}$ ingested. Values on the right side from the flex do not yet show to approach the climax (plateau) at dosages tested. Actually, no toxicity information nor lethal doses on pigs are available after the ingestion of acorns tannins, at dosages higher than $1.72 \mathrm{~g}$ of TAE $\cdot \mathrm{kg}^{-1} \mathrm{BW} \cdot \mathrm{d}^{-1}$. No toxicity episodes could effectively be pointed out at a maximum ingestion of $1.72 \mathrm{~g}$ of TAE $\cdot \mathrm{kg}^{-1} \mathrm{BW} \cdot \mathrm{d}^{-1}$ and animals appeared healthy as no clinical signs of poisoning could be recorded throughout the trial. Nevertheless, the comparison of body weight gain (as percentage of BW at beginning) of pigs from the different groups after one week of experimental feeding, slopes down according to acorns combining in the diet: the consumption of $70 \%$ or $50 \%$ acorns combined diets lead to lower weight gains, up to $4.5 \%$ less at a comparison to body weight gain of pigs fed on $0 \%$ of acorns in the diet.

\section{Discussion}

In the light of such findings, it can be clearly assessed

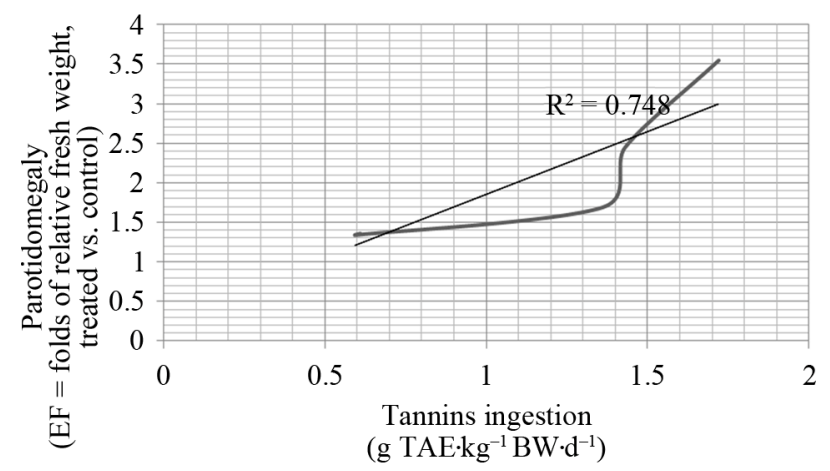

Figure 2. Dose-response of parotidomegaly (enlargement factor, EF) on acorns tannins (load of $g$ tannic acid equivalent, TAE with the diet) daily intake, expressed as amounts per $\mathrm{kg}$ of body weight (BW). The sigmoid curve identifies the increase of parotid gland response for tannins loads higher than $1.4 \mathrm{~g}$ TAE $\cdot \mathbf{k g}^{-1} \mathrm{BW} \cdot \mathrm{d}^{-1}$. Efficacy Dose $50 \%$ $\left(E D_{50}\right)$ and Lethal Dose $50 \%\left(L_{50}\right)$ fall out of the interval of tannins doses considered. that the chemical composition of the diet modulate salivary glands activity. Betscher, et al. (2010) [60], reported that the physical form of the diet is able to influence the mucins produced (neutral and acid mucins) by the mandibular gland in the young pig, confirming the comparable effects they reported to raise in the intestine [61]. More, results obtained so far on pigs and other species, according to own previous trials, state the role of saliva as a first mechanism of defence and supposed to be involved in a buffering effect to protect oesophageal and gastric mucosa [62]. The mechanism has been shown to be linked to the gene expression encoding for tannin binding salivary proteins under dietary tannins stimulation, mimicking isoproterenol activity in lab animals and other animal species $[63,64]$.

The surviving strategies adopted by some animal species to optimize the utilization of plants and parts of them as food sources, lead to the physiological "adaptation" towards dietary tannins in some animal species. The increase of salivary mucoproteins (PRPs) by parotid gland plays a buffering role against dietary tannins, with a triple goal: salivary tannins binding proteins play an important role for the oral health and prevent from damages on mucosal layers of the next alimentary tracts, by the formation of tannin-proteins precipitates; salivary tannin binding proteins, including basically proline rich proteins (PRPs), are composed of high amounts of a non-essential aminoacid (proline), showing a selective affinity to tannins, due to physico-chemical peculiarities and open loose spatial structure: in this way, the attempt to save essential aminoacids from the proteins precipitating activity exerted by tannins enhances the evolutionary countermeasure against the detrimental effects; the complexes tannins/proteins, with special regards to mucoproteins and PRPs, aim to a reduction of digestive enzymes in binding tannins, thus saving the utilization of nutrients: tannins-enzymes precipitates in the chyme can determine lower digestibility rates for impaired enzymatic activity. To such an extent, acorns are normally consumed by animals during fall and winter: both domestic and wild boars particularly appreciate such fruits from oaks [65]. Acorns are classified as achaenia, from an entire ovary with ovary walls developed into a wooden pericarp. According to Holman and Robbins (1944) [66] they are indehiscent, one-seeded hard fruits. Acorns from most of species of oaks are edible ones, but some are too small or too hard to be used as food [67]. More than 500 species of Oaks are spread out all over the world, differing in chemical composition and polyphenols contents. In general terms, literature reports that condensed tannins represented about $1 \%-2 \%$ of DM $[65,68,69]$, across different botanical species of oaks, while hydrolizable tannins are much more abundant and can range from $5 \%$ up to $10 \%$ on DM $[65,68,70]$. The use of acorns as food is known since ancient times and the worldwide 
deployment across cultures and centuries is well documented in traditional recipes, above all for flour and bread production, but also for oil extraction [67,71-76]. In recent times, acorns started to be re-considered from a nutraceutical point of view: scientists' interest actually focussed on different topics (antioxidant, antimicrobial, antiparasitic, antimutagenic activity, etc.) as said, as acorns are known to provide high amounts of polyphenols. Nevertheless, due to the different properties of acorns tannins and the contrasting biological activities exerted once ingested, the reaction observed in pigs as animal models, towards different amounts of dietary tannins, highlights a clear response to limit the negative effects (proteins precipitating effects), as first. The bioavailability of polyphenolic compounds can reasonably be reduced by such defence mechanisms when acorns tannins are provided by the diet: to such an extent, beneficial properties of tannins assessed by in vitro trials should take into account the host response and a series of complex physiological interactions (based on genetic biodiversity) when results from in vivo trials don't match in vitro experiences. As a matter of facts, pigs tolerate high intake of acorns, in contrast to other animal species and the way they cope with tannins detrimental effects started to be observed systematically by parotid glands modification assessment here reported according to different tannins dosages. On the other hand, episodes of toxicity or lethal effects were observed in ruminants, horses and rabbits, even after small amounts of acorns consumption: actually, no toxicity could be pointed out during the experimental feeding for one week, or four weeks as stated before in own trials, despite lower daily gain weight could be determined in pigs fed on acorns combined diets, likely due to low energy density, high crude fiber and low crude protein supply.

So, the parotid gland hypertrophy shows to be a constant finding when dietary acorns tannins are ingested by pigs and its grades are strongly correlated to tannins dosages ingested: the higher $\mathrm{g} \mathrm{TAE} \cdot \mathrm{kg}^{-1} \mathrm{BW} \cdot \mathrm{d}^{-1}$, the larger the parotid gland mass resulted. Permanent vs. transient parotidomegaly and hypertrophy grades induced by high amounts of dietary acorns tannins ingestion are still on debate.

\section{REFERENCES}

[1] H. H. Dukes, "Prehension, Mastication, Salivary Secretion, Deglutition," In: H. H. Dukes, Ed., The Physiology of Domestic Animals, 7th Edition, Comstock Publishing Associate, Ithaca, 1955, pp. 303-321.

[2] J. E. Beart, T. H. Lilley and E. Haslam, "Plant Polyphenols-Secondary Metabolism and Chemical Defence: Some Observations," Phytochemistry, Vol. 24, 1985, pp. 33-38. doi:10.1016/S0031-9422(00)80802-X

[3] K. W. Tipton, E. H. Floyd, J. G. Marshall and J. B.
McDevitt, "Resistance of Certain Grain Sorghum Hybrids to Bird Damage in Louisiana," Agronomy Journal, Vol. 62, No. 2, 1970, pp. 211-213. doi:10.2134/agronj1970.00021962006200020010x

[4] R. W. Bullard, J. O. York and S. R. Kilburn, "Polyphenolic Changes in Ripening Bird-Resistant Sorghum," Journal of Agricultural and Food Chemistry, Vol. 29, No. 5, 1981, pp. 973-981. doi:10.1021/jf00107a022

[5] D. L. Dreyer, J. C. Reese and K. C. Jones, "Aphid Feeding Deterrents in Sorghum. Bioassay, Isolation and Characterization," Journal of Chemical Ecology, Vol. 7, No. 2, 1981, pp. 273-284. doi:10.1007/BF00995750

[6] H. B. Harris and R. E. Burns, "Relationship between Tannin Content of Sorghum Grain and Preharvest Seed Molding," Agronomy Journal, Vol. 65, No. 6, 1973, pp. 957-959. doi:10.2134/agronj1973.00021962006500060033x

[7] Y. Henis, H. Tagari and R. Volcani, "Effect of Water Extracts of Carob Pods, Tannic Acid, and Their Derivatives on the Morphology and Growth of Microorganisms," Applied Microbiology, Vol. 12, 1964, pp. 204-209.

[8] Y. A. Geidarn, A. G. Ambali and P. A. Onyeyili, "Preliminary Phytochemical and Antibacterial Evaluation of Crude Aqueous Extract of Psidium guajava Leaf," Journal of Applied Science, Vol. 7, No. 4, 2007, pp. 511-514.

[9] H. Akiyama, K. Fujii, O. Yamasaki, T. Oono and K. Iwatsuki, "Antibacterial Action of Several Tannins against Staphylococcus aureus," Journal of Antimicrobial Chemotherapy, Vol. 48, 2001, pp. 487-491. doi: $10.1093 / \mathrm{jac} / 48.4 .487$

[10] R. E. Benoit and R. Starkey, "Enzyme Inactivation as a Factor in the Inhibition of Decomposition of Organic Matter by Tannins," Soil Science, Vol. 105, 1968, pp. 203-208. doi:10.1097/00010694-196804000-00001

[11] A. R. Collins, "Assays for Oxidative Stress and Antioxidant Status: Applications to Research into the Biological Effectiveness of Polyphenols," American Journal of Clinical Nutrition, Vol. 81, 2005, pp. 261-267.

[12] A. Scalbert, I. T. Johnson and M. Saltmarsh, "Polyphenols: Antioxidants and beyond," American Journal of Clinical Nutrition, Vol. 81, 2005, pp. 215-217.

[13] C. L. Keen, R. R. Holt, P. I. Oteiza, C. G. Fraga and H. H. Schmitz, "Cocoa Antioxidants and Cardiovascular Health," American Journal of Clinical Nutrition, Vol. 81, 2005, pp. 298-303.

[14] M. Baumann and W. Muller, "The Effects of Tannin Containing Plants on Pathogenic Microorganisms," Tierärztl Umsch, Vol. 48, 1993, pp. 738-741.

[15] S. A. Sotohy, W. Muller and A. A. Ismail, "In Vitro Effect of Egyptian Tannin-Containing Plants and Their Extracts on the Survival of Pathogenic Bacteria," Dtsch Tierarztl Wochenschr, Vol. 102, 1995, pp. 344-348.

[16] K. Funatogawa, S. Hayashi, H. Shimomura, T. Yoshida, T. Hatano, H. Ito and Y. Hirai, "Antibacterial Activity of Hydrolyzable Tannins Derived from Medicinal Plants against Helicobacter pylori," Microbiology and Immunology, Vol. 48, 2004, pp. 251-261.

[17] A. H. Smith and R. I. Mackie, "Effect of Condensed Tan- 
nins on Bacterial Diversity and Metabolic Activity in the Rat Gastrointestinal Tract," Applied and Environmental Microbiology, Vol. 70, 2004, pp. 1104-1115. doi:10.1128/AEM.70.2.1104-1115.2004

[18] T. Taguri, T. Tanaka and I. Kouno, "Antimicrobial Activity of 10 Different Plant Polyphenols against Bacteria Causing Food-Borne Disease," Biological \& Pharmaceutical Bulletin, Vol. 27, 2004, pp. 1965-1969. doi:10.1248/bpb.27.1965

[19] R. Puupponen-Pimiä, L. Nohynek, S. Hartmann-Schmidlin, M. Kähkönen, M. Heinonen, K. Määttä-Riihinen and K. M. Oksman-Caldentey, "Berry Phenolics Selectively Inhibit the Growth of Intestinal Pathogens," Journal of Applied Microbiology, Vol. 98, 2005, pp. 991-1000. doi:10.1111/j.1365-2672.2005.02547.x

[20] A. Van Parys, F. Boyen, J. Dewulf, F. Haesbrouck and F. Pasmans, "The Use of Tannins to Control Salmonella Typhimurium Infections in Pigs," Zoonoses Public Health, Vol. 57, No. 6, 2010, pp. 423-428. doi:10.1111/j.1863-2378.2009.01242.x

[21] B. R. Min and S. P. Hart, "Tannins for Suppression of Internal Parasites," Journal of Animal Science, Vol. 81, 2003, pp. 102-109.

[22] S. Maity, J. R. Vedasiromoni and D. K. Ganguly, "AntiUlcer Effect of the Hot Water Extract of Black Tea (Camelia sinensis)," Journal of Ethnopharmacology, Vol. 46, 1995, pp. 167-174. doi:10.1016/0378-8741(95)01245-9

[23] F. Borrelli and A. A. Izzo, "The Plant Kingdom as a Source of Anti-Ulcer Remedies," Phytotherapy Research, Vol. 14, 2000, pp. 581-591. doi:10.1002/1099-1573(200012)14:8<581::AID-PTR776 $\geq 3.0 . \mathrm{CO} ; 2-\mathrm{S}$

[24] L. M. Sànchez Perera, D. Ruedas and B. C. Gòmez, "Gastric Antiulcer Effect of Rhizophora mangle L.," Journal of Ethnopharmacology, Vol. 77, 2001, pp. 1-3. doi:10.1016/S0378-8741(01)00277-X

[25] S. Das, R. Prakash and S. N. Devaraj, "Antidiarrhoeal Effects of Methanolic Root Extract of Hemidesmus indicus (Indian Sarsaparilla)-An In Vitro and In Vivo Study," Indian Journal of Experimental Biology, Vol. 41, 2003, pp. 363-366.

[26] T. Okuda, K. Mori and H. Hayatsu, "Inhibitory Effect of Tannins on Direct-Acting Mutagens," Chemical \& Pharmaceutical Bulletin, Vol. 32, 1984, pp. 3755-3758. doi:10.1248/cpb.32.3755

[27] Z. Y. Wang, S. J. Cheng, Z. C. Zhou, M. Athar, W. A. Khana, D. R. Bickers and H. Mukhtar, "Antimutagenic Activity of Green Tea Polyphenols," Mutation Research/ Genetic Toxicology, Vol. 223, 1989, pp. 273-285.

[28] H. Imanishi, Y. Sasaki, T. Ohta, M. Watanabe, T. Kato, and Y. Shirasu, "Tea Tannin Components Modify the Induction of Sister-Chromatid Exchanges and Chromosome Aberrations in Mutagen-Treated Cultured Mammalian Cells and Mice," Mutation Research/Genetic Toxicology, Vol. 259, 1991, pp. 79-87.

[29] M. L. Kuo, K. C. Lee and J. K. Lin, "Genotoxicities of Nitropyrenes and Their Modulation by Apigenin, Tannic Acid, Ellagic Acid and Indole-3-Carbinol in the Salmo- nella and CHO Systems," Mutation Research/Fundamental and Molecular Mechanisms of Mutagenesis, Vol. 270, 1992, pp. 87-95.

[30] S. C. Chen and K. T. Chung, "Mutagenicity and Antimutagenicity Studies of Tannic Acid and Its Related Compounds," Food and Chemical Toxicology, Vol. 38, 2000, pp. 1-5. doi:10.1016/S0278-6915(99)00114-3

[31] L. T. Wu, C. C. Chu, J. G. Chung, C. H. Chen, L. S. Hsu and J. K. Liu, "Effects of Tannic Acid and Its Related Compounds on Food Mutagens or Hydrogen PeroxideInduced DNA Strand Breaks in Human Lymphocytes," Mutation Research, Vol. 556, 2004, pp. 75-82. doi:10.1016/j.mrfmmm.2004.07.004

[32] H. Szaefer, M. Cichocki, D. Brauze and W. BaerDubowska, "Alteration in Phases I and II Enzyme Activities and Polycyclic Aromatic Hydrocarbons-DNA Adduct Formation by Plant Phenolics in Mouse Epidermis," $\mathrm{Nu}$ trition and Cancer, Vol. 48, 2004, pp. 70-77. doi:10.1207/s15327914nc4801_10

[33] H. Szaefer, J. Kaczmarek, M. Rybczyńska and W. BaerDubowskaa, "The Effect of Plant Phenols on the Expression and Activity of Phorbol Ester-Induced PKC in Mouse Epidermis," Toxicology, Vol. 230, 2007, pp. 1-10. doi:10.1016/j.tox.2006.10.001

[34] G. Galati and P. J. O’Brien, "Potential Toxicity of Flavonoids and Other Dietary Phenolics: Significance for Their Chemopreventive and Anticancer Properties," Free Radical Biology \& Medicine, Vol. 37, 2004, pp. 287-303. doi:10.1016/j.freeradbiomed.2004.04.034

[35] M. Matsuyama, T. Nakamura, H. Suzuki and T. Nagayo, "Morphogenesis of Duodenal Adenocarcinoma Induced by N-ethyl-N'-nitro-N-nitrosoguanidine in Mice and Rats," Gann Monograph on Cancer Research, Vol. 17, 1975, pp. 269-281.

[36] S. Yoshizawa, T. Horiuchi, H. Fujiki, T. Yoshida, T. Okuda and T. Sugimura, "Antitumor Promoting Activity of (-)Epigallocatechin Gallate, the Main Constituent of Tannins in Green Tea," Phytotherapy Research, Vol. 1, 1987, pp. 44-47. doi:10.1002/ptr.2650010110

[37] H. Mukhtar, M. Das, W. A. Khan, Z. Y. Wang, D. P. Bik and D. R. Bickers, "Exceptional Activity of Tannic Acid among Naturally Occurring Plant Phenols in Protecting against 7,12-dimethylbenz(a)anthracene-, benzo(a)pyrene-, 3-methylcholanthrene-, and tv-methyl-tv-nitrosourea-induced Skin Tumorigenesis in Mice," Cancer Research, Vol. 48, 1988, pp. 2361-2365.

[38] Y. Fujita, T. Yamane, M. Tanaka, K. Kuwata, J. Okuzumi, T. Takahashi, H. Fujiki and T. Okuda, "Inhibitory Effect of (-)Epigallocatechin Galle on Carcinogenesis with N-ethyl-N'-nitro-N-nitrosoguanidine in Mouse Duodenum," Japanese Journal of Cancer Research, Vol. 80, 1989 , pp. 503-505. doi:10.1111/j.1349-7006.1989.tb01666.X

[39] L. L. Yang, C. Y. Lee and K. Y. Yen, "Induction of Apoptosis by Hydrolyzable Tannins from Eugenia jambos L. on Human Leukemia Cells," Cancer Letters, Vol. 157,2000 , pp. 65-75. doi:10.1016/S0304-3835(00)00477-8

[40] S. Nam, D. M. Smith and Q. P. Dou, "Tannic Acid 
Potently Inhibits Tumor Cell Proteasome Activity, Increases p27 and Bax Expression, and Induces G1 Arrest and Apoptosis1," Cancer Epidemiology, Biomarkers \& Prevention, Vol. 10, 2001, pp. 1083-1088.

[41] D. B. Wells, H. D. Humphrey and J. J. Coll, "Relation of Tannic Acid to Liver Necrosis Occurring in Burns," New England Journal of Medicine, Vol. 226, 1942, pp. 629636. doi:10.1056/NEJM194204162261601

[42] B. Korpassy, "Tannins as Hepatic Carcinogens," Progress in Experimental Tumor Research, Vol. 2, 1981, pp. 245-290.

[43] J. A. Neser, J. A. Coetzer, J. Boomker and H. Cable, "Oak (Quercus rubor) Poisoning in Cattle," Journal of South African Veterinary Association, Vol. 53, 1982, pp. 151-155.

[44] T. F. Warner and E. A. Azen, "Tannins, Salivary ProlineRich Proteins and Oesophageal Cancer," Medical Hypothesis, Vol. 26, 1988, pp. 99-102. doi:10.1016/0306-9877(88)90060-6

[45] B. W. Cousins, T. D. Tanksley Jr., D. A. Knabe and T. Zebrowska, "Nutrient Digestibility and Performance of Pigs Fed Sorghum Varying in Tannins Concentration," Journal of Animal Science, Vol. 53, 1981, pp. 1534-1537.

[46] H. Mehansho, L. Butler and D. M. Carlson, "Dietary tannins and Salivary Proline Rich Proteins: Interactions, Induction, and Defense Mechanism," Annual Review of Nutrition, Vol. 7, 1987, pp. 423-440. doi:10.1146/annurev.nu.07.070187.002231

[47] A. J. M. Jansman, "Tannins in Faba Beans (Vicia faba L.): Antinutritional Properties in Monogastric Animals," Ph.D. Dissertation, Wageningen University, Wageningen, 1993.

[48] R. Lizardo, J. Peiniau and A. Aumaitre, "Effects of Sorghum on Performance, Digestibility of Dietary Components and Activities of Pancreatic and Intestinal Enzymes in the Weaned Piglets," Animal Feed Science and Technology, Vol. 56, 1995, pp. 67-82. doi:10.1016/0377-8401(95)00813-3

[49] A. Schiavone, K. Guo, S. Tassone, L. Gasco Hernandez, E. R. Denti and I. Zoccarato, "Effects of Natural Extract of Chestnut Wood on Digestibility, Performance Traits and Nitrogen Balance of Broiler Chicks," Poultry Science, Vol. 87, 2008, pp. 521-527. doi:10.3382/ps.2007-00113

[50] T. Shimada and T. Saioth, "Negative Effects of Acorns on the Wood Mouse Apodemus speciosus," Researches on Population Ecology, Vol. 45, 2003, pp. 7-17.

[51] T. Takahashi and T. Shimada, "Selective Consumption of Acorns by the Japanese Wood Mouse according to Tannin Content: A Behavioral Countermeasure against Plant Secondary Metabolites," Ecological Research, Vol. 23, 2008, pp. 1033-1038. doi:10.1007/s11284-008-0473-5

[52] A. Bennick, "Salivary Proline-Rich Proteins," Molecular and Cellular Biochemistry, Vol. 45, 1982, pp. 83-99. doi:10.1007/BF00223503

[53] P. J. Austin, L. A. Suchar, C. T. Robbins and A. E. Hagerman, "Tannin Binding Proteins in Saliva of Deer and Their Absence in Saliva of Sheep and Cattle," Journal of Chemical Ecology, Vol. 15, 1989, pp. 1335-1347. doi:10.1007/BF01014834
[54] C. McArthur, G. D. Sanson and A. M. Beal, "Salivary Proline-Rich Proteins in Mammals: Roles in Oral Homeostasis and Counteracting Dietary Tannin," Journal of Chemistry Ecology, Vol. 21, 1995, pp. 663-691. doi:10.1007/BF02033455

[55] M. G. Cappai, P. Wolf, V. Grosse-Liesner, A. Kastner, G. Nieddu, W. Pinna and J. Kamphues, "Effect of Whole Acorns (Quercus pubescens) Shred Based Diet on Parotid Gland in Growing Pigs in Relation to Tannins," Livestock Science, Vol. 134, 2010, pp. 183-186. doi:10.1016/j.livsci.2010.06.136

[56] M. Clauss, J. Gehrke, J.-M. Hatt, E. S. Dierenfeld, E. J. Flachm, R. Hermes, J. Castell, W. J. Streich and J. Fickel, "Tannin-Binding Salivary Proteins in Three captive Rhinoceros Species," Comparative Biochemistry and Physiology, Vol. 140, 2005, pp. 67-72. doi:10.1016/j.cbpb.2004.11.005

[57] P. R. Astatt and T. Ingram, "Adaptation to Oak and Other Fibrous, Phenolic-Rich Foliage by a Small Mammal, Neotoma fuscipes," Oecologia, Vol. 60, 1983, pp. 135142. doi:10.1007/BF00379333

[58] C. Naumann and R. Bassler, "Die Chemische Untersuchung von Futtermitteln (Chemical Analysis of Animal Feed)," VDLUFA-Verlag, Darmstadt, 2004.

[59] P. G. Waterman and S. Mole, "Analysis of Plant Metabolites," In: P. G. Waterman and S. Mole, Eds., Methods in Ecology Series, Blackwell Scientific Publications, Oxford, 1994.

[60] S. Betscher, A. Beineke, S. Hansen, A. Mößeler, S. Kleinschmidt and J. Kamphues, "Type of Mucus Produced in Salivary Glands of Young Pigs Fed Diets of Different Physical Form (Grinding Intensity, Meal/Pellets)," Proceedings of the 14th Congress of the European Society of Veterinary and Comparative Nutrition, Zürich, 6-8 September 2010, p. 46.

[61] S. Betscher, A. Beineke, L. Schönfeld and J. Kamphues, "Effects of Diet's Physical Form (Grinding Intensity; Meal/Pellets) on Morphological and Histological Parameters (e.g. Ratio of Neutral to Acid Mucins) of the Gastrointestinal Tract in Weaned Piglets," Livestock Science, Vol. 134, 2010, pp. 149-151. doi:10.1016/j.livsci.2010.06.122

[62] J. Kamphues, V. Grosse-Liesner, S. Betscher, A. Mösseler, P. Wolf, M. Wintermann, S. Hansen and A. Beineke, "Saliva and Oesophageal Secretion-'Missing Links' in the Pathogenesis of Gastric Ulcers in Pigs?" Proceedings of the 13th Congress of the European Society of Veterinary and Comparative Nutrition, Oristano, 15-17 October 2009, p. 43.

[63] H. Mehansho, S. Clement, B. T. Sheares, S. Smith and D. M. Carlson, "Induction of Proline-Rich Glycoprotein Synthesis in Mouse Salivary Glands by Isoproterenol and by Tannins," The Journal of Biological Chemistry, Vol. 260, 1985, pp. 4418-4423.

[64] D. K. Ann, S. Clements, E. M. Johnstones and D. M. Carlson, "Induction of Tissue-Specific Proline-Rich Protein Multigene Families in Rat and Mouse Parotid Glands by Isoproterenol," The Journal of Biological Chemistry, Vol. 262, 1987, pp. 899-904. 
[65] W. Pinna, M. G. Cappai, G. Moniello and G. Nieddu, "Tannins Concentration and Ultrastructural Peculiarities of Starch Granules in Acorns of Quercus Ilex L., Quercus Pubescens Willdenow and Quercus Suber L.," Proceedings of the 11th Congress of the European Society of Veterinary and Comparative Nutrition, Leipzig, 1-3 November, 2007, p. 96.

[66] R. M. Holman and W. W. Robbins, "A Textbook of General Botany," Wiley and Sons, Inc., New York, 1944.

[67] D. A. Bainbridge, "Symposium on Multiple-Use Management of California's Hardwoods," San Luis Obispo, California, 1986.

[68] T. Shimada and T. Saito, "Re-Evaluation of the Relationship between Rodent Populations and Acorn Masting: A Review from the Aspect of Nutrients and Defensive Chemicals in Acorns," Population Ecology, Vol. 48, 2006, pp. 341-352. doi:10.1007/s10144-006-0012-6

[69] D. Tejerina, S. García-Torres, M. Cabeza de Vaca, F. M. Vázquez and R. Cava, "Acorns (Quercus rotundifolia Lam.) and Grass as Natural Sources of Antioxidants and Fatty Acids in the 'Montanera' Feeding of Iberian Pig: Intra- and Inter-Annual Variations," Food Chemistry, Vol. 124, 2011, pp. 997-1004. doi:10.1016/j.foodchem.2010.07.058

\section{Abbreviations:}

PG: Parotid Gland;

TAE: Tannic Acid Equivalent; PRP: Proline Rich Proteins;

PPA: Protein Precipitating Activity;
[70] E. Cantòs, J. C. Espín, C. López-Bote, L. de la Hoz, J. A. Ordóñez and F. A. Tomás-Barberán, "Phenolic Compounds and Fatty Acids from Acorns (Quercus spp.), the Main Dietary Constituent of Free-Ranged Iberian Pigs," Journal of Agricultural and Food Chemistry, Vol. 51, 2003, pp. 6248-6255. doi:10.1021/jf030216v

[71] J. W. Hudson, "Preparation of Acorn Bread by Pomo Indians," American Anthropologist, Vol. 2, 1900, pp. 775-776.

[72] H. E. Driver, "The Acorn in North American Indian Diet," Proceedings of the Indiana Academy of Science, 1953, pp. 52-62.

[73] P. D. Goodrum, "Food of the Indians: Acorn Breads," Pacific Historians, Vol. 17, 1973, pp. 77-80.

[74] G. W. Dimbleby, "Plants and Archaeology," Paladin Books, St. Albans, 1978.

[75] D. A. Bainbridge, "Quercus, a Multi-Purpose Tree for Temperate Climates," International Tree Crops Journal, Vol. 3, 1986, pp. 291-298. doi:10.1080/01435698.1986.9752800

[76] D. A. Bainbridge, "The Rise of Agriculture: A New Perspective," Ambio, Vol. 14, No. 3, 1985, pp. 148-151.

DM: Dry Matter;

TBP: Tannins Binding Proteins;

BW: Body Weight;

HE: Hematoxylin-Eosin;

PAS: Periodic Acid-Schiff Stain. 